\title{
Corporate Governance and Capital Groups in Poland*
}

\author{
Maria Aggestam ${ }^{* *}$
}

The process of systemic change in Poland has brought about major changes in corporate governance. The enforcement of new laws has created a culture of compliance that has shaped capital groups and the management ethos of the groups, spurring them to improve. It is argued that the Polish versions of capital groups are markedly different from their western counterparts as they reflect unique historical patterns and socio-economic environments. The purpose of this paper is to discuss governance structures within capital groups from their transformation, institutionalization contingencies. Describing current forms of capital groups, the focus is on governance issues illustrated by two capital groups. Building on the Weimer/Pape (1999) framework, a taxonomy is proposed which contrasts governance in Poland with other economic systems. The paper concludes with preliminary theses about trends and current challenges for governing capital groups.

Der Prozess des Systemwechsels in Polen hat viele grosse Veränderungen in Corporate Governance mit sich gebracht. Das Inkrafttreten neuer Gesetze schuf eine Kultur der Nachgiebigkeit, die die Vermögensgruppen und die Managementethik dieser Grupen formte und sie zur Verbesserung anspornte. Es wird behauptet, dass polnische Kapitalgruppen aufgrund ihres historischen Hintergrundes und sozioökonomischen Umfelds sich von ihren Pendants im Westen unterscheiden würden. Der Aufsatz diskutiert Strukturen von Corporate Governance innerhalb Kapitalgruppen anhand der Transformation und Institutionalisierung Aktuelle Formen der Kapitalgruppen werden beschrieben, der Fokus liegt jedoch auf Führungsfragen, die anhand zweier Kaputalgruppen erläutert werden. Basierend auf dem System von Weimer/Pope (1999) wird eine Taxonomie vorgeschlagen, die die Führung in Polen anderen Wirtschaftssystemen gegenüberstellt. Der Aufsatz schliesst mit vorläufigen Thesen über Trends und aktuelle Herausforderungen für Kapitalgruppen ab.

Key words: Corporate Governance / capital groups / transition economy / Poland

\footnotetext{
* Manuscript received: 26.08.02, accepted: 12.12 .03 (1 revision)

** Maria Aggestam, Professor, Department of Business Administration, University of Lund. Main research interests: Corporate governance and development of capital groups in times of environmental jolts. Corresponding address: Maria.aggestam@fek.lu.se
} 


\section{Introduction}

Extensive and complex governance systems have evolved over centuries in "western" types of market economies. In Poland, one of the primary challenges faced by corporate governance stems from the breakdown of the old and the enforcement of the new socio-economic system. Market-focused laws, policies, administrative practices and controls, supporting institutions and managerial cultures were in their infancies in the beginning of 1990 (Wawrzyniak et al. 1998; 2002). The lack of experience and absence of model behavioral patterns to follow were impediments to building an efficient base for the growth of firms. Other impediments included weak judicial systems, underdeveloped institutions and financial sector, scarce human resources, and complex ownership structures. The business environment lacked the institutional and professional infrastructures needed for a competitive marketplace. Also, institutional investors overrelied on debt financing and were not yet strong enough to demand fairness, efficiency and transparency of actions. Such conditions created an environment of ups and downs with steady gains in corporate governance. The process, however, was extremely fragile and struggling for survival.

Over the last ten years, privatization programs have transformed the economic landscape in Poland by transferring government-controlled assets into private hands. The process of de-nationalization of the state assets started in the 1990s and a variety of developments in the grass-rooted companies helped to overcome environmental jolts (Aggestam 2002) and then provided enthusiastic endorsement of the steps to economic recovery. The challenges of the environmental jolts also offered opportunities for the state and the private sector to change behaviour and existing rules of the game. In the most turbulent environment in the recent history, the marketization of the companies presented unique challenges to the restructuring of the firms and their managing rapidly changing politics, technology and markets. These firms faced the need to realign radically their competitive assets with rapidly changing market conditions with full cognition of the ongoing turbulent evolution of their environments. The economic argument in favour of reforming the economy was to improve the allocative efficiency and competitiveness of the industries and operating firms in order to promote economic growth of these companies. The privatization of state-owned enterprises was the key element of the transformation, enabling the founding process and creation of "capital groups" operating on the basis of defined ownership rights. "Capital groups" are a Polish version of business groups that are legally independent, joined together by distinguishing mechanisms such as, e.g., ownership relationship, forms of corporate governance, and usage of resources. In other words, capital groups are defined here as a set of companies within connected industries pursuing common development strategies. The main goals of the transitioning capital groups were to improve the efficiency within firms and to lead to better overall 
economic performance. The reforming of the public assets was critical to an effective partnership relationship. Another important effort was building consensus and sharing expertise and other resources and assets among the players. Moves towards business concentrations and building the private or semi-private sector were generally oriented towards strengthening the market positions and sustaining the economic power of the firms involved.

With little worldwide attention, the rise of new governance structures in Poland and other Central European countries had fundamentally transformed these economies. The result is an incomplete understanding of the distinctive Polish governance process and the rise of "capital groups", a Polish version of business group. This paper addresses this gap and some issues that are central to corporate governance. Corporate governance is a framework of legal, institutional and cultural factors shaping the pattern of influences which stakeholders exert on managerial decision-making (Weimer/Pape 1999). The paper also provides insights into transitional processes during the initial stages in the development of capital groups in Poland.

The aim of the present paper is to examine the special character of corporate governance issues associated with capital groups in privatized companies in Poland. This character is important in fostering an efficient governance structure and is to be placed in the perspective of three parallel processes: transformation, institutionalization and collateralization. Those processes created new imperatives for Polish companies to be part of and participate in the new (for the country) market logic of the international economy. Research on Polish corporate governance is very new and started only over the last decade. This paper contributes to knowledge on corporate governance and capital groups in Poland by bringing together insights about socio-economic aspects. The study was primarily descriptive and multiprocedural. It was based on annual and quarterly reports and accounts, a variety of archival sources, newspaper reports and publicly available official documents.

The main point of this paper is that the corporate governance and capital groups in Poland are unique and reaching increasingly into the business life in Poland. The central argument advanced here is that developments of corporate governance within capital groups in Poland were shaped by current socioeconomic developments. This paper is best understood as an essay employing both theoretical conceptualizations and some empirical examples in order to enhance the understanding of corporate governance and the problems of capital groups. More specifically, this paper focuses on how, for example, the creation of National Investment Funds (NIF) became a powerful presence that continually influenced the process of group transition. Finally, the study focuses on the overall operation of two groups: the National Investment Fund and the Exbud S.A as illustrative examples. This paper does not discuss the portfolio companies. 
The establishment of capital groups in Poland was linked to processes of internationalization and concentration of business operations and to enterprises aiming to achieve competitive market advantages and goals. There were usually strategic goals, for example, limiting uncertainty and risk, using the synergy effect and effect of scale, in order to consolidate a competitive position. What was specific to establishing capital groups in Poland was the creation of capital and organizational constructions as a result of marketization processes in stateowned companies and as a result of the implementation of the mass privatization program (NIFs). From this point of view, the emergence of capital groups was also the effect of political and social decisions that created broad social support for the transformation processes.

The paper has three parts: (1) introduction and clarification of the contribution of the study; (2) description of the corporate governance and capital groups in Poland; and (3) illustration of the origin and characteristics of two capital groups. The paper concludes with review of challenges to the operation of the capital groups.

\section{Corporate Governance}

The theoretical roots of corporate governance date from 1932 when Berle and Means conducted their seminal investigation of the control system in the American corporation. In Europe and especially in Central European countries such research was scarce. The processes of transformation and internationalization occurring in the Polish economy and the implementation of market regulations have led to increased interest in issues of corporate governance (Aggestam/Stobińska 2002; Bossak/Zalega 2001; Koładkiewicz 1999; 2002; Wawrzyniak et al. 1998).

Weimer and Pape (1999), in summarizing research on corporate governance focused on country-level systems of corporate governance and listed eight characteristics that describe the salient features of different systems. They include the following: the prevailing concept of the firm; the board system; the salient stakeholders able to exert influence on managerial decision-making; the importance of stock markets in the national economy; the presence or absence of an external market for corporate control; the ownership structure; the extent to which executive compensation is dependent on corporate performance; and the time horizon of economic relationships (Turnbull 1997:153). Corporate governance at the firm-level is related to these characteristics. Weimer and Pape also point to work by Scott (1985), deLong (1989), Moerland (1995) and Weimer (1995) as indicating four groupings or styles of corporate governance systems among relatively rich, industrialized countries: Anglo-Saxon; Germanic; Latin; and Japan. The Polish system appears to be a mixture of the Germanic and Anglo-Saxon styles. The four different systems in the Weimer- 
Pape taxonomy include but differently emphasize the eight characteristics which are included in the main corporate governance structures and processes.

Table 1. Taxonomy of systems of Corporate Governance*

\begin{tabular}{|c|c|c|c|}
\hline System/Style & Anglo-Saxon & Germanic & Polish Mixture \\
\hline Orientation & Market-oriented & Market-oriented & Network-oriented/market-oriented \\
\hline Country & $\begin{array}{l}\text { USA, UK, } \\
\text { Canada, } \\
\text { Australia }\end{array}$ & $\begin{array}{l}\text { Germany, } \\
\text { Netherlands, } \\
\text { Switzerland, } \\
\text { Sweden, Austria, } \\
\text { Denmark, } \\
\text { Norway, Finland }\end{array}$ & Poland \\
\hline Concept of firm & $\begin{array}{l}\text { Instrumental, } \\
\text { shareholder- } \\
\text { owned } \\
\end{array}$ & Institutional & Institutional \\
\hline Board system & $\begin{array}{l}\text { One-tier } \\
\text { (executive and } \\
\text { non-executive }\end{array}$ & \begin{tabular}{|l} 
Two-tier \\
(executory and \\
supervisory
\end{tabular} & $\begin{array}{l}\text { Two-tier (executive and } \\
\text { supervisory board) }\end{array}$ \\
\hline $\begin{array}{l}\text { Salient } \\
\text { stakeholders }\end{array}$ & Shareholders & $\begin{array}{l}\text { Industrial banks } \\
\text { (Germany), } \\
\text { employees, in } \\
\text { general } \\
\text { oligarchic group }\end{array}$ & $\begin{array}{l}\text { Financial holdings, the } \\
\text { government, families, banks, other } \\
\text { financial institutions }\end{array}$ \\
\hline $\begin{array}{l}\text { Importance of } \\
\text { stock market in } \\
\text { the national } \\
\text { economy }\end{array}$ & High & Moderate/high & Moderate/high \\
\hline $\begin{array}{l}\text { Active external } \\
\text { market for } \\
\text { corporate control }\end{array}$ & Yes & No & No \\
\hline $\begin{array}{l}\text { Ownership } \\
\text { concentration }\end{array}$ & Low & Moderate & Moderate/high \\
\hline $\begin{array}{l}\text { Performance- } \\
\text { dependent } \\
\text { executive } \\
\text { compensation }\end{array}$ & High & Low & Moderate/low \\
\hline $\begin{array}{l}\text { Time horizon of } \\
\text { economic } \\
\text { relationships }\end{array}$ & Short term & Long term & Short term \\
\hline
\end{tabular}

* Adapted by the author from Weimar-Pape 1999

Accordingly, the Anglo-Saxon style describes corporate governance in the United States, United Kingdom, Canada and Australia. The Germanic style describes governance processes in Germany, the Netherlands, Switzerland, Sweden, Austria, Denmark, Norway and Finland. The Latin system of corporate governance includes France, Italy, Spain and Belgium. The Japan system includes corporate governance processes in Japan. As with other taxonomies 
attempting to describes differences among national characteristics, structures or practices (e.g., Hofstede, 1985), the factors and the classifications in the Weimer-Pape scheme are illustrative and heuristic rather than authoritative. The factors along which corporate governance processes can be compared and the tentative groupings or systems of governance in the Weimer-Pape taxonomy are of interest to conceptualizations here. A re-presentation of the Weimer-Pape (op cit. 1999:154) taxonomy is made in Table 1 with special reference to Poland. In this taxonomy, the eight descriptors of corporate governance are related to the two main systems, that is, Germanic and Anglo-Saxon. Corporate governance in Poland is seen as a mixture of these two systems.

\section{Creation of Corporate Governance Systems in Poland}

Research in various governance-related fields poses unique theoretical and practical challenges. Research generally finds that corporate governance systems are subject to local, institutional and cultural conditions (Aggestam/Stobińska, 2002; Tricker, 1984; Wawrzyniak et al., 1998; Weimer/Pape 1999). In Poland, due to protracted privatization reforms, corporate governance systems are very young and continually developing. In the near absence of models to follow, Polish governance systems have had to evolve a language for describing the nexus of the new systems of rule-making, political and economic coordination and guidance for solving problems across and beyond the newly privatized companies. That has posed an increasing demand in recent years for research on corporate governance in Poland (Wawrzyniak 2002). The demand has also been fueled by the desire to overcome strategic disadvantages and firm's agency problems in increasingly turbulent market. Research is also challenged to provide attention to how corporate governance influences the formulation and attainment of goals and organizational strategies in larger economic units.

Corporate governance is a framework of legal, institutional and cultural factors shaping the pattern of influences which stakeholders exert on managerial decision-making (Weimer/Pape 1999). In other words, corporate governance provides for internal and external pressures on management to take decisions in the interests of stakeholders of the firm. In Poland those internal and external mechanisms were weak (Dharwadkar/Brandes 2000). One example is the privatization of Krosno by the Polish state-body (individual investor, 28 percent equity; employees, 12 percent; a local firm 10 percent; the Polish development bank, 15 percent: and the state-body 35 percent) has to be regarded as weak internal and external governance. Poland does not have effective internal and external governance mechanisms that can diminish traditional principalmanager problems (Carlin/Aghion 1996). More experienced economies that lack strong internal governance can use external governance as a substitute. In Poland, firms are not required to send shareholder proxies prior to meeting, a 
practice that can limit shareholder actions. Adding to the unique situation, the Polish business landscape is characterized by small illiquid capital markets and underdeveloped bankruptcy mechanisms (EBRD 1998).

Through corporate governance, managerial decision-making is made to focus on creating value for the stakeholders through adroit uses of intellectual capital (Keenan/Aggestam 2001). Broadly, the governance system structures the distribution of corporate control rights over stakeholders including shareholders, board members and the managerial core. In Poland, governance systems are characterized by their persistent rules and regulations, sheer energy and sometimes-controversial practices (Kolodko 2000). They are ideologically focused on the market and largely technocratic, relying on rules and regulations as control mechanisms for compliance. Little attention has been shown to how stakeholders think, feel and act. Such human factors were important to accomplishing the efficiencies dictated by the reforms.

In a capital group where ownership and management are separated, agency problems become critical. Making strategic organizational decisions in each group's corporate governance is affected by the key actors, for example, managers, employees, shareholders, the competition, customers, state administration (Tricker 2000; Weimer/Pape 1999). Corporate governance of the firms and the process of formulating their goals is focused, on one hand, on meeting the challenges for implementing new institutional solutions and, on the other, by a multitude of personal interests and motives.

The corporate governance system in Poland can generally be characterized as market- or short-term shareholder-oriented (Dockery/Herbert 2000) but also in some cases network-oriented (Trocki 1998) with a two-tier board: a supervisory board and central management board. In NIFs the governance rests upon a system of accountability involving monitoring, evaluation and control of the firms under their management.

\section{Capital Groups in Poland: Development Paths}

The establishment of capital groups in Poland is largely linked to the process of the state withdrawing from direct ownership, implemented after 1989. While marshalling support for corporate governance reform, the state nevertheless occupied a central position in the economy by being both a dominant shareholder and as an establisher of regulatory devices in the process of creating market-oriented mechanisms (Morawski 1998). This was evidenced not only in the administrative mode of implementing market regulations but also through the state's direct involvement in the market as a "substitute" owner. The government's involvement in the founding and ownership of companies was a special challenge to economic reform in Poland and has affected the operation of capital groups. 
Poland moved slowly into the process by privatizing 500 companies, a procedure that initiated a state-created investment fund as a control mechanism over shareholders in each privatized company. To assure that the 'equal access vouchers' (Hashi 2000) created by the state would control individuals investing in privatized companies, Poland designed "voucher investment funds". Creation of private investment funds did not initially allow individuals to invest directly in the stock of newly privatized companies. Polish law mandated that individuals could invest their voucher certificates only in a state-created financial intermediary called the National Investment Funds (NIFs) which served as a mechanism to control shareholders of the privatized companies (Lewandowski/Szyszko 1999). The funds were given the status of joint stock companies competent for enlarging the assets of transformed firms into companies included in the funds (Koladkiewicz 1999; Sztyber 1997). Only fifteen NIFs were chartered, each being assigned a controlling $33 \%$ of shares in the 500 privatized firms. The balance of the stock in each company was held by other NIFs and by the state (Simonetti et al. 1999). In the companies where NIFs held a controlling stake special management companies were employed to advise on restructuring those companies. The composition of NIFs, that is, capital groups, in terms of shares and the role of their electorate (foreign and domestic) was significant. Polish banks were members of nine of the NIFs groups. NIFs No: 12, 10, 6 and 2 launched their operations with higher sectoral specialization. Polish institutions had a majority share in three of NIFs (NIFs No: 1, 2, and 3). In six NIFs (No: 5, 6, 8, 10, 12, 13), a single foreign institution had a majority control (over $50 \%$ ) over the management company, and in four other cases (No 4, 7, 14, 15), the joint shares of foreign partners held control of the management company. In NIF No 11 there was no identifiable group as majority control of the management company. NIF No 9 never had a fund manager. Overall, this system encouraged serious problems. One of the major problems was delaying the privatization processes by political infighting over diverse issues such as, for example, selection of a management company that was capable of running the NIFs. Another problem was that its activities have become significantly politicized. The result was that in 1998 only 253 companies out of 15 NIFs were listed on the Warsaw Stock Exchange (PAP News Service 1998). The Polish system deliberately created its stock exchange so it could play the classic role of being the energizer of economic growth and barometer of its economic status.

For certain, capital groups in Poland have not been developed in a political or economical vacuum. There has been a shift away from the complex nature and form of earlier highly politicized concentrations of companies. In recent years, newer capital groups have emerged with the distinctive extensive form and function of economic and political networks and pressure groups. Aggestam/Stobińska, (2002) identified four development paths of capital groups in Poland based upon Romanowska's (1998) study of capital and 
organizational concentration. The groups differ depending upon the role and the principal motivation of the state. There are two types of state involvement: as substitute owner and as guarantor of market regulation. The state also has two motives: political or economic. The aim was to achieve political approval and economic advantage in increasingly turbulent market. Thus, there are four combinations of capital groups: (1) capital groups which were started by the state as the substitute owner and for political purposes; (2) groups that were started by the state as a substitute owner and for economic reasons; (3) capital groups that were started with the state as a guarantor of market regulations and for political purposes; and (4) capital groups started with the state as guarantor of market regulation and for economic reasons. Table 2 illustrates this taxonomy.

\section{Table 2. The Origin of Capital Groups in Poland}

\section{Type of state involvement}

Substitute owner

Guarantor of market

regulation of economic

relations

\begin{tabular}{|c|c|}
\hline NIFs & $\begin{array}{c}\text { KGHM (Copper Company) } \\
\text { Katowice Steel Mill } \\
\text { Sendzimir Steel Mill }\end{array}$ \\
\hline Coal companies & ELEKTRIM \\
Sugar holding-companies & AGROS \\
& EXBUD \\
\hline Political & Economic
\end{tabular}

Motives

Source: Adopted from: Aggestam and Stobinska, 2002.

The coal companies and sugar holding companies are examples of a combination of political motives and the state's role as a guarantor of market regulation of economic relations. The creation of NIFs exemplifies the domination of political goals and the state's role as a substitute owner in the transformation processes. In other words, it is a state-centric conception. For example, creating capital groups, e.g., KGHM Polska Miedź, Katowice Steel Mill and Sendzimir Steel Mill, from the previously state-owned bodies was due to privatization of the companies, market inefficiency, underdeveloped capital market and other economic motives. New market regulations based on economic imperatives aimed at enabling transformation of the companies resulted in capital groups such as Elektrim, Agros and Exbud. The position of those newly created groups provided new challenges including, for example, the need to manage effectively and efficiently complex workforces, establish new understandings of buyer-supplier agreements, and adapt to practical requirements of international standards and other transaction-related challenges. 


\section{Pressures on Corporate Governance in Capital Groups}

The goals and strategies of capital groups are established early at their point of origin. Inscribed into their existence are the ways in which the capital group will continue to respond to extrinsic that is, external, and intrinsic, that is, internal forces. External influences on corporate governance are exerted by the government, markets, investors, and customers. Intrinsic influences are exerted by the managerial core and employees. Over the life time of the capital groups these influences play a continuous role. The capital group can adjust in four ways. It can adapt to or resist the external forces and it can adapt to or resist internal forces.

\section{Adaptation to extrinsic force:}

In response to external force the capital group changes its rules, regulations and decision making processes. This option includes gradually redefining the goals, structures and methods of operation in meeting market and other external influences. By being set up by the government, the NIFs are examples of adapting to external forces. Companies are differently affected. For some companies, the external influence results in deep restructuring for achieving a competitive position on the market. For other companies, the external influence provides a life saving association with more successful companies, thus survival.

\section{Adaptation to intrinsic force:}

This option involves setting goals and mobilizing resources in response to internal pressures. Such pressures can be focused on better utilization of resources and improving a competitive position. The influences come from managers and employees. An example of adaptation of to intrinsic force was the capital group KGHM Polska Miedź whose management strategized improving the group's position in the international market.

\section{Resistance to extrinsic force:}

This is an option involving avoiding or blocking influences from external forces. The resistance is toward being subordinated to governmental, regulatory, stockholder or market pressures. This option often involves mobilizing political resources to avoid the changes. An example of a capital group resisting external pressure was in a case of coal companies whose ingrained procedures and narrow product line, as well as employee resistance, militated against changing. 


\section{Resistance to intrinsic force:}

In this option the management of the capital group resists pressures from employees and managers for change. The changes may be in redefining goals, changing structure and methods of operation, or seeking new opportunities in the market. Whatever the reason for resisting the internal pressures, the established ways of doing business persist. Exbud provides an example of a capital group that resisted internal pressures to some extent. Eventually, extrinsic forces prevailed and the capital group was acquired by a foreign investor which discharged the management and re-defined structure and methods of operations.

The origin of capital groups in Poland also defines the basic orientation of the mechanisms for exercising corporate governance. The Polish transformation, particularly, the uniquely situational administrative implementation of reforms, the parallel implementation of economic and social goals, and the weak capital market, has resulted in corporate governance solutions similar to the networkoriented model (Wawrzyniak et al. 1998). A basic assumption of networkoriented relationships is that parties are mutually dependent upon resources controlled by another, and that there are gains to be realized by the pooling of resources (Powell 1990). The network form of governance according to Morgan (1991:2) is somehow impervious to the market and hence not yet influenced by the 'bottom line' imperatives of the market-oriented system. Network-oriented models represent a coalition of interests and remain a significant feature of the new governance order. A special feature of this model from the point of view of the present paper is an institutional understanding of a group as an autonomous economic unit forming a coalition of different actors - shareholders, managers, employees, suppliers, national and local authorities, etc., who aim to preserve the company's continuity (Weimer/Pape 1999). The preservation of the group's continuity is the most urgent problem due to the decline of economy and to the managerial inefficiency. This situation opens up possibilities for the development of different configurations of influence - dominated by outsiders (externally oriented actors, shareholders) vs. dominated by insiders (internally oriented actors), and different configurations - based on control of internal resources vs. control of the possibilities created by the market. This allows identifying two ways of exercising corporate governance: the internally oriented method and the externally-oriented method. The internally-oriented type is focused on improving the group's market position and competitive edge and fulfilling managerial' and shareholder interests. The externally-oriented type is oriented toward maximizing the effects of the group's functioning and fulfilling mainly the shareholders' interests (e.g. financiers and creditors). This is illustrated in Figure 1. 


\section{Strategies For Growth of Capital Groups}

Capital groups in Poland have adopted various strategies in order to stay alive and grow. A new infrastructure of corporate governance has evolved which presents problems and limitations. Capital groups in Poland are not immune to complex governance problems. As with all capital groups, management and organization are problematic (Dockery/Herbert 2000). For example, mechanisms for guaranteeing investments by owners and financiers are only in their infancies and are unable to protect the interests of outside stakeholders.

Fig 1. Directions of Corporate Governance

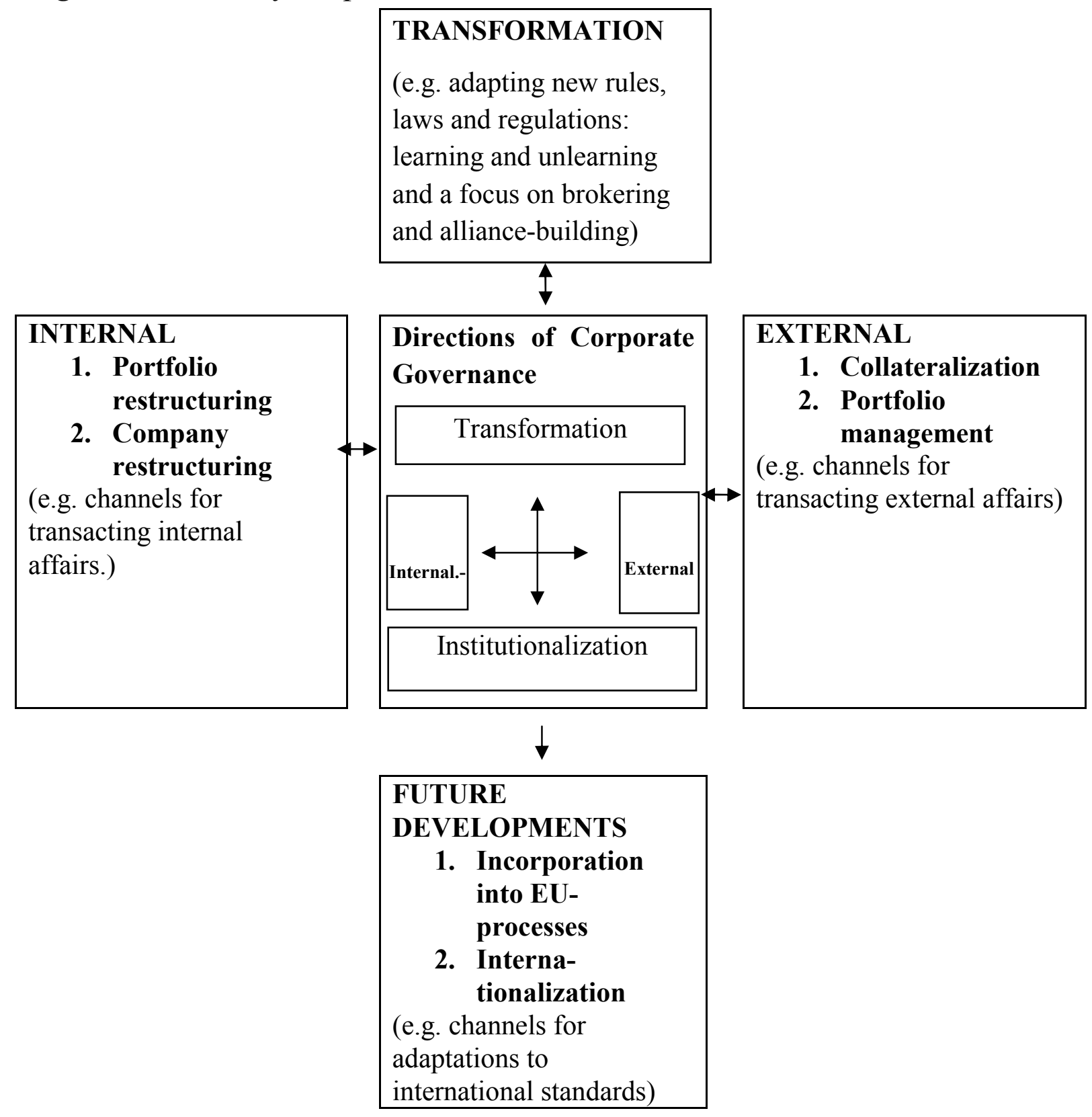


At the analytical core of corporate governance is a concern by contested authority structures. Accordingly, the focus is on evolving system of (formal and informal) economic and political coordination across multiple levels of firms' authorities. Although this system transcends variety of conflicting questions circulating around shift how corporate governance affairs and transboundary firm's problems are governed. For me, and many other researchers (Koladkiewicz 2002; Wawrzyniak 2002) these developments represent the evolving new infrastructure of a fragile system of corporate governance. Governing capital groups is a process of never-ending restructuring, collateralizing, portfolio restructuring and managing shareholders portfolio. Restructuring refers to strategies oriented mainly toward carrying out organizational restructuring activity in subsidiaries with the aim of increasing their market value. This strategy assumes there is no pressure to downsize the weakest companies, because firms can still create wealth or values for its stakeholders after appropriate changes. Collateralization refers to strategies oriented toward selective support for subsidiaries' operations, diminishing number of firms that "don't fit" the portfolio and acquiring shares in companies in the sector and outside the group. The strategy involves an active policy in shaping the fund's portfolio according to the sector criterion. Portfolio restructuring concerns strategies oriented mainly toward increasing the value of the shareholders' portfolio by supporting economically strong subsidiaries and acquiring shares in companies from outside the group. Restructuring processes carried out by the companies are assisted in some way by the fund, but this is not the dominating strategy. Portfolio restructuring and managing of the shareholders' portfolio refers to strategies oriented toward trade within companies. These are activities aimed at searching for foreign investors and an active strategy in relation to minority stakes.

\section{A Note on Methodology}

There is a growing consensus that macro-analysis of the socio-economic situation in one country does not always translate globally or universally. The socio-cultural and economic environment of Poland is unique, diverse and complex. Mirroring such diversity, the development and evolution of Polish firms and in particular their governance has been diverse. The Polish socioeconomic and cultural architecture has both allowed and fostered special, diverse consequences for the design and functioning of firms and their corporate governance. In the context of its unique business environment, corporate governance in Poland has had a different evolution and character. Therefore, the phenomena studied here should be approached with a discriminating eye or what Denzin (1994) called the 'art of interpretation'. He argued that interpretation is a difficult task for the researcher who is trying to make sense of what has been learned. All that has been learned and understood 
gives rise to a new body of conceptualizations to be further communicated to the reader.

The meta-analysis method was used for gathering the data for this paper. Metaanalysis is a quantitative method of combining results from other studies (Hunter/Schmidt 1999; Sama/Papamarcos 2000). The cumulative approach required professional judgments about what information was relevant and about data and sources of data. Having this in mind I sought to collect and select information from various secondary sources that would allow me to accumulate data pertinent to the focus of this paper. The sources included: (1) books; (2) academic journals and periodicals; (3) non-academic journals and periodicals; (4) daily press and media information; (5) working papers from various research institutes (6) statistics and reports from international organizations; (7) reports and programs conducted by Polish university, and (8) narrowly-focused research programs documented in internal reports by a Polish university.

These secondary sources were supported by comparative statistics and accounts from the European Bank of Reconstruction and Development (EBRD); and research papers from the World Bank, Washington, DC; OECD (http://www.oecd.org). The paper also uses statistics and other information gathered from the KBN research program conducted by a Polish university in Poland during 1995- 1997 and 1990-2000 by Professor B. Wawrzyniak and documented in his book "Polish Capital Group, European Perspective", issued in 2002. Some of those original sources of my inquiry may present a difficulty to the international reader as they are published entirely in Polish language.

\section{Illustrations 1: Exbud Group}

The previous section has described the development and dynamics of corporate governance in Poland. In this section, I illustrate two of the capital groups and their complexities

Exbud S.A. was established in October 1977 as an Export Bureau coordinating the export services of a regional group of construction enterprises. The privatization process of Exbud began in the early 1990s and resulted in a capital group that comprised: (a) Exbud joint-stock company conducting its own business operations and coordinating the operations of the group; (b) the company's representative offices abroad, conducting limited business operations; (c) single-owner limited-liability companies established by Exbud S.A. with 100-percent Exbud S.A. ownership, functioning as separate business units with their own business operations; and (d) companies with mixed capital (including foreign capital) in which Exbud S.A. held minority stakes.

In the first half of the 1990s Exbud S.A. took an active part in the processes of ownership restructuring, that is, investing in business units within the 
construction sector and outside it (e.g. publishing a regional daily newspaper, printing color magazines).

The strategy of diversifying business operations was aimed at maintaining the group's financial stabilization in a turbulent environment. During the second half of the 1990s the group consistently implemented a strategy of building a major position in the construction sector. Exbud's strategy for the years $1999 / 2000$ included a target $2.5 \%$ share in this market. This goal was to be reached by measures including the development of operations in sectors with the lowest investment potential (housing, road and hydro-engineering construction' and construction for the needs of the energy sector), acquisitions of new companies operating in these sectors, increasing existing stakes in companies, and implementing planning and controlling systems in project execution.

Figure 2. Exbud-Skanska S.A.

\begin{tabular}{|l|l|l|}
\hline Corporate Stuff & Senior Executive Staff & \begin{tabular}{|l|}
\hline Skanska Teknik \\
\hline
\end{tabular} \\
\hline
\end{tabular}

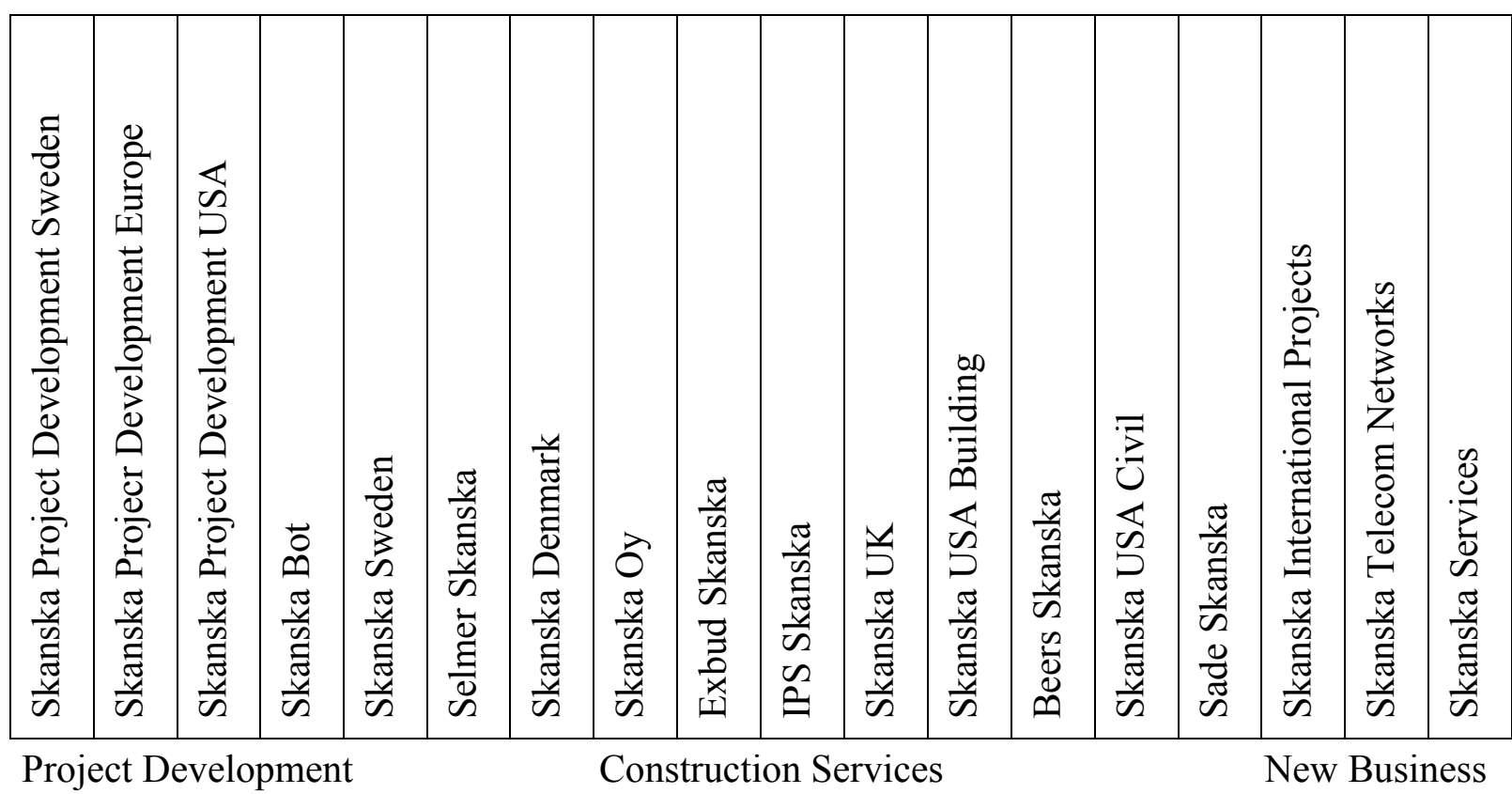

An expansive investment policy under conditions of the deteriorating situation in the construction market in the late 1990s led to the decline of the group's financial condition. Threatened by a hostile takeover in 1999, Exbud undertook ultimately successful action toward a takeover by a strategic investor - Skanska $\mathrm{AB}$ (Swedish based multinational). In the Skanska AB group, Exbud plays the role of a local partner, i.e., a company whose operations focus exclusively on the Polish market. The ownership changes led to the company's restructuring. The core businesses - general and industrial construction, hydro-engineering 
construction and road construction - were separated out and coordinated by sector leaders from other companies within the Exbud group. Exbud become a part of an international cooperation but focused entirely on the Polish market.

The takeover of Exbud by a strategic investor had a significant impact on the mechanisms of corporate governance in the Exbud S.A. group. One characteristic feature of corporate governance at Exbud prior to the takeover by Skanska AB was extensive autonomy of the company's Management Board. This was facilitated by the company's ownership structure whereby major shareholders formed a group of inactive institutional investors (a British and an Austrian bank held $5-10 \%$ of the shares), while the remaining shareholders comprised a numerous group of foreign and Polish investors, including a sizable group from the company's top management. The strong position of the Management Board (as a result of dispersed shareholding) guaranteed it an influence on decisions concerning the takeover of the Supervisory Board, in which the company's employees were the majority. At the same time, documents specifying the competencies of the company's owner-related bodies did not offer the Supervisory Board possibilities of interfering with the work of the Management Board. Thus, the Supervisory Board's role was in fact limited to accepting any actions undertaken by the Management Board. The founding owner's governance method over subsidiaries in Exbud group formally comprised four elements (the Exbud Management Board, the subsidiaries' Management Boards, the subsidiaries' Supervisory Boards, the founding owner control bureau and functional specialist offices). In view of the ambiguousness of the competence and responsibility of these bodies, and in spite of Exbud's strong ownership position in the subsidiaries, effective influence over the subsidiaries was problematic. In effect, the subsidiaries' management boards enjoyed a large degree of autonomy in making strategic decisions, all the more so since the companies' Supervisory Boards copied the non-interfering style of conduct of Exbud's Supervisory Board. The management viewed the strong position of the Exbud Management Board and the extensive strategic independence of the subsidiaries as the strength of corporate governance in the group. However, this model of founding owners controlling became the source of substantial problems: (i) the impossibility of developing a uniform market strategy for the group; (ii) the subsidiaries' making decisions against the interests of the owner; (iii) limited possibilities of consolidating operations within the group.

The system of corporate governance in the Exbud S.A. group after the takeover by the strategic investor changed significantly both at the capital group level and at the subsidiary level. These changes consisted in introducing the corporate governance model used by Skanska AB. This model includes: (1) mutual structural and personnel ties to the companies' bodies; (2) the presence of managerial groups as an element of operational management; (3) following 
uniform procedures in terms of economics and finance; and (4) expanding local principles of exercising corporate governance.

To date, corporate governance in Exbud SA has included four major developments: [1] introduction of the principle of corporate management in the dominating unit and the subsidiaries; this corporate principle means that a Management Board includes employed members, but also, as non-employed members, members of the operating unit's Management Board; this principle is implemented at all of the group's operative levels; [2] appointment of a managerial group in August 2000 (at the level of the dominating unit), which included the Exbud S.A. Management Board Chairman as well as the management board chairmen of the sector leader companies and key functional managers. The managerial group acted as an advisory body to the group Management Board and was responsible for organizing business processes and consolidating the operations of all the units of the group; [3] implementation of the uniform (binding all Skanska AB units in the world) system of budgeting, preparing financial statements, verifying and evaluating investment projects; and [4] maintaining (in accordance with the requirements of the Commercial Code in force in Poland) the principle of corporate governance being exercised by the Supervisory Board.

Exbud was present in the EU market as early as the 1980s but operations in this market were hampered by restrictions resulting from the EU's protectionist policy toward non-EU companies. For example, on the German market Exbud was discriminated and could only operate as a sub-contractor and only in selected administrative regions. Exbud's takeover by Skanska AB potentially makes made it easier and opens the door for the group to operate in European markets. However, being included in the structure of a global corporation does not mean that Exbud will automatically start operating in markets outside Poland, especially because as a local partner, Exbud has no influence over Skanska AB's strategic decisions. The future prospects for Exbud joining the race on international markets may depend upon: (i) the strategy of the Skanska AB. group toward its local partner and (ii) Exbud's position on the domestic market.

\section{Illustration 2: NIF No. 2}

NIFs in Poland are capital groups created by way of the state's involvement in building new financial environment and new organizational structures that fulfill economic, political and socio-economic goals. The organization of the NIFs gives them a significant influence on the operations of their subsidiaries and substantial autonomy in shaping their funds' strategies with respect to sector holding companies, portfolio funds and venture capital. That is why NIFs are interesting as subject for study. 
National Investment Funds are not like the investment funds in western economic practice - oriented toward portfolio investment and not contributing to management of subsidiaries. The basic goal of National Investment Funds, set in the law on NIFs, is to increase the funds' assets by increasing the market value of the companies in which the funds hold shares (through restructuring of subsidiaries, consolidating their market position, ensuring them international links) and to conduct business operations and trade in company shares. (Law of April 30, 1993 on national investment funds and their privatization). NIFs by definition are capital groups that are unions of jointly managed companies in strategic areas. NIFs are subject to legal regulations that define the rules of managerial accountancy and auditing and the preparation of consolidated financial statements.

Founding-owner governance and subsidiary company management strategies are the result of the funds' features: [a] they are closed-end funds organized in the form of joint-stock companies; [b] they are special privatization funds but are governed by bodies specified in the Commercial Code; [c] from the point of view of investment policies, they can be described as active funds aiming to increase their assets by increasing the value of shares in companies in which they are shareholders; [d] a specific aspect that complicates management of the funds and exercising of owner governance is the participation of management companies in that management; and [e] the funds have specified investment restrictions a factor that is important for developing and implementing corporate governance strategies.

During the period between 1996-1999, National Investment Fund No. 2 made some important changes in its strategy that influenced the capital group's functioning. In the first period, the fund carried out tasks resulting from the law and in the subsequent period the fund's strategic goals up to 2003 were developed. In accordance with the Law of April 30, 1993 on National Investment Funds and their privatization, in 1995-1997 NIF No. 2 operated as a typical restructuring fund. The basic goal was to increase the value of company shares contributed to the fund. NIF No. 2 did not exercise broad sector diversification of its portfolio, focusing on selecting companies offering good development prospects and those promising results that would increase the companies' effectiveness and profitability. A new strategy, developed in May 1998 and approved for implementation in June 1998, involved the evolutionary change of NIF No. 2 into a venture-capital-type fund, that is, a fund combining the features of venture capital (financing small and medium-sized businesses with the aim of maximizing profit from investment, with a higher risk) with elements of a restructuring and balanced fund. NIF No. 2's strategic goal is the long-term growth of the firm value effected through increased net profit per share and increased value of net assets per share. It is expected that increase in firm value will result from forward-looking investments, revenues, dividends and other profits. It is also expected that increase in share prices will 
incorporate the effects of change in-group strategy and betterment in governance system.

NIF No. 2 is meant to be universal, that is, with no sector or regional specialization, hence the strategy of diversifying shares and not concentrating on specific types of companies or investing in certain sectors of operation. The main source of funds for NIF No. 2 is the capital market, and debt financing is used only provisionally, that is, in situations of temporary inadequacy of financial resources. This is a significant reorientation of the strategy for 19982003 in comparison with the governance strategy of 1995-1997. Reports shows that restructuring action has been taken and completed at the subsidiary companies in all areas of operation - market, product, technology, finance, employment, organization and management. All 34 NIFs companies have completed market restructuring which was aimed at seeking new markets and customers, changing the product portfolio, and changing marketing activity. Asset restructuring mainly involved liquidating, selling off, and giving away assets, setting a company's legal status in order concerning ownership, spinning off subsidiaries and creating a holding-company structure. Asset restructuring was not carried out in two companies (out of 34). Organizational restructuring included changes in organizational structure, implementing new methods of managing the company, developing programs and action-plan and establishing capital links with local partners. Employment restructuring mainly consisted in reducing employment - various forms of employee layoffs, changing the employment structure, changes of management board members, changing the rules of remuneration and new employee training. Financial restructuring was not carried out in eight companies and wherever it was carried out it was based mainly on legislation created within the 1993 Law on company and bank restructuring. Financial restructuring included cost optimization, the introduction of new methods of managing liquidity and share portfolios, leasing, cash-free settlements, a search for more effective ways of recovering amounts due, and reductions of loan debts.

Ownership restructuring involved spinning off companies, seeking a strategic investor, sale and acquisition of shares in other companies, share issues, going public, and being listed on the Warsaw Stock Exchange. No ownership restructuring was undertaken in 15 companies. Twenty-eight companies undertook technological projects aimed at improving product quality and competitiveness, effected product restructuring and took action to improve profitability. The completed restructuring measures brought positive effects in most of the companies. They failed in a small group, that is, 3 out of 34 of these companies declared bankruptcy. The companies carried out the restructuring in stages, starting with actions considered to be priorities, e.g., actions aimed at maintaining or developing the market and the product, marketing projects, modernization projects, technology upgrading. In the second stage the companies focused on changes in management, introducing new methods of 
remuneration, deepening structural changes in the organization, implementing quality standards and environmental-protection projects.

Corporate governance at NIF No. 2 comprises a complex arrangement resulting from the origins of the group -that is, from the moment the State Treasury formed this institution. In accordance with the Commercial Code in force in Poland, the company's governing bodies are the general shareholders' meeting, the Supervisory Board and the Management Board. However, under the Mass Privatization Program the funds' assets were to be managed by institutions described as managerial firms. Those managerial firms were carrying out functions as a governing body for the whole group. Those companies also filled the role of an advisory body to the Supervisory Board in terms of defining the fund's goals and investment policy, its capital structure, provision of guarantees and distribution of profit. Implementing these arrangements at NIF No. 2 (similarly to the other National Investment Funds) was complicated by mismanagement within the group that led to specific problems stemming from the imprecise definition of the relations between the prerogatives, duties and responsibilities of the management company's management board and the fund's Supervisory Board. To bring order to these relations, in the first stage of managing NIF No. 2 an arrangement was made whereby members of the Fund Management Board were also members of the managing company's Management Board).

This simplification of the relations between the Fund Management Board and the managing companies became complicated. Conflict among management responsibilities still remained however. There arose the question of whether Management Board members were accountable to the Fund or to the "management company". These problems were of special importance at NIF No. 2 due to the fact that the management company represented a consortium comprising Polish and foreign companies whose interests were not always identical. Growing conflicts in the Management Board worried the Supervisory Board that persistently demanded improved management efficiency at the Fund, and after two years of trial and error, this led the Supervisory Board to decide to terminate the contract with the "management company". For the following two years NIF No. 2 operated by itself, supported by its own specialists. Most of the time the leaders of firms lacked a clear vision-of the future that would link to product profitability, efficiency and faster time to market. The situation was difficult and complex and for firms it was often the matter of survival. In 1999 the Fund's Supervisory Board signed a contract with a new 'managing company'.

In general, the relations between founding-owner governance methods and its subsidiaries of the Fund are defined by two factors: [a] the specificity of the NIF as a capital group and [b] the specific coalition of power in the Fund, 
resulting from the introduction of 'managing companies'. Broadly, those factors included mixture of rule-making, political authority and power.

The level of the Fund's active involvement in shaping strategic decisions in the subsidiaries was largely determined by the size of the stake held (according to the law, the size of the leading share package was $33 \%$ of shares) and the ban on selling off shares from the leading share package for the first three years. These solutions forced the fund into an active stance toward the companies. This included, for example, active participation in the obtaining of information; monitoring the company's operations; and enhanced performance toward mutual benefits and profits tied up to ownership. The Fund exercised its owner rights toward the subsidiaries through its representatives on the companies' supervisory boards. Cooperation between company supervisory boards and company management boards focused on the following problems such as: restructuring of the company; seeking market opportunities; forecasting the situation in the sector; and changes in the capital structure. The scope of this cooperation was largely the result of the goals inscribed into the operations of the National Investment Funds. The weakness of the cooperation lay in the supervisory board, with its noticeable lack of qualified professionals, taking an inactive stand in decision-making processes. Another pressure for intensive restructuring and sound corporate governance was the increasing competition from the EU. It created an uncertain environment in which defects in governance only exacerbated the problems of Polish companies.

\section{Concluding Remarks}

The Exbud S.A. group was one of the first companies formed as a result of the privatization of a multiple-facility state-owned enterprise. Acquisitions made in successive years led to the formation of a conglomerate that comprised 27 companies in the year 2000. The diversification strategy implemented in the first half of the 1990s, aimed at better adaptation to the conditions of an uncertain environment, evolved visibly in the second half of the 1990s toward a sector consolidation with the goal of strengthening the group's competitive position.

An analysis of corporate governance in the NIF's, as illustrated in NIF No. 2, confirms that in the early stage it was oriented to mechanisms regulating the market and characterized by active restructuring measures. In later stages, NIFs governance was focused on improving investment efficiency. The corporate governance had evolved: it had added portfolio management to company restructuring.

As governance evolved in NIFs there was less of a tendency to adopt intrinsic changes and more of readiness to become actively involved in affecting conditions extrinsic to the NIFs. In part, this meant influencing legislative 
mechanisms, combating dishonest competition, accelerating privatization, reorienting the tax system to be pro-investment, and protecting domestic enterprises. The uncertainties remained in the legislative process and were a principal concern of corporate governance in NIFs. This caused energy to be spent in consensus-building. These modes of governance, influenced in a variety of ways by diversified firms, reconfigured the state-body power and authority. Accordingly, governance poses with renewed immediacy the question of how the firms should be governed and how the transboundary problems are governed. Further transformation of the NIFs will result from continuous smallscale adjustments and from incremental rather than dramatic changes.

Reflecting on corporate governance in NIFs and Exbud, certain similarities and difference can be noted. In both cases success depended upon ownership-shift. In the case of the NIFs, the ownership was principally the state-body which was in reality a combination of intrinsic and intrinsic forces. Accordingly, in Exbud, there was a similar situation especially since the takeover by Skanska AB. Exbud's current ownership is also a combination of intrinsic and extrinsic influences on governance. A new governece infrastructure were taking seeds in both groups reaching ever more deeply into "in house" affairs concerning responsibility for governance and enlargement into effectiveness of operations in the face of market pressures.

To sum up, mass privatization took longer and was different in Poland compared to other transitional economies (Aggestam/Stobińska, 2002: Dockery/Herberet, 2000). The main reason was the absence of political consensus and wide-spread corruption among various interest groups (Hashi, 2000). Operating in the competitive market economy was hampered by unethical legal practices and business behaviors and the lack of market-oriented infrastructures. Multiple, diffuse ownership and inadequate corporate controls allowed insiders to strip assets and leave less value for the minority shareholders. However, the two examples of capital groups, the NIFs and Exbud SA, were pioneering in building their institutions and their professional capacity for corporate governance.

The NIFs, with the state in a double role as provider of venture capital and as investor, have now been fully privatized with their shares listed on the stock exchange. They are now profitable and face stock market pressures for sound corporate governance. The Exbud S.A. group has been taken over by an outsider investor and is positioned to be more competitive and adjusting to world standards. Paradoxically, the takeover has limited the group's operation to the Polish construction market. Both the NIFs and Exbud S.A. appear to be evolving toward internationally-oriented corporate governance and integration into the EU. This will mean an insistence on efficiency, business ethics, fairness and transparency that is central to operating competitively in the world market. 


\section{References}

Act of Parliament on national investment funds and their privatization - April 30, 1993. [Ustawa z dnia 30 kwietnia 1993 roku o narodowych funduszach inwestycyjnych i ich prywatyzacji (Dz. U. nr 44, poz. 202)].

Aggestam, M. (2002): Managerial Sensemaking During Systemic Change in Polish Companies. Unpublished doctoral dissertation. Leon Kozminski Academy of Management and Entrepreneurship. Warszawa.

Aggestam, M./Stobińska, K. (1999): Capital Groups in Poland: Logic of Development, International Conference Report of Management - Business and Managers Facing the Challenges of the 21-st Century, IV edition, Academy of Management and Entrepreneurship, Warsaw.

Aggestam, M. /Stobińska, K. (2002): Capital Groups in Poland: Governing the New Structures. Swedish Network for European Studies in Economics and Business, Molle.

Berle, A./Means, G. (1932): The Modern Corporation and Private Property. New York: McMillan Co.

Bossak, J./Zalega, K. (2001): Efektywnosc corporate governance a kierunki rozwoju rynku kapitalowego w Polsce, (Effectivity of corporate governance and direction of development of capital market in Poland) Organiszacja i Kierowanie, 4 (106), 1-25.

Carlin, W./Aghion, P. (1996): Restructuring outcomes and the evolution of ownership patterns in central and Eastern Europe, Economic of Transition, 4, 371-388.

Coffee, J. (1999): Privatization and corporate governance: The lessons from securities market failure, Journal of Corporation Law, 25, 1-39.

Dharwadkar, R./George, G./Brandes, P. (2000): Privatization in emerging economies: An agency theory perspective, Academy of Management Review, Vol. 25, 650-669.

Denzin, N. (1994): The art and politics of interpretation, in: Denzin, N./Lincoln, Y.: Handbook of Qualitative Research, Sage Publications, 501-515.

De Wit, B./Meyer, R. (1998): Strategy. Process, Content, Context. International, Business Press, New York.

Dockery, E./Herbert, W. (2000): Corporate governance and enterprise restructuring in transition economies: evidence from privatized Polish companies, Managerial Finance, 26 (9), 80-92.

European Bank for Reconstruction and Development (EBRD) (1998): Transition report 1998: Financial sector in transition, London.

Fligstein, N. (1990): The Transformation of Corporate Control, Harvard University Press, London, England.

Gierszewska, G./Stobińska, K. (2000): Corporate Governance Impact on Strategy Building in National Investment Fund Companies: In Search of Effective Corporate Governance System, Management Studies Center, Warsaw.

Hashi, I. (2000): The Polish National Investment Fund program: Mass privatization with a difference?, Comparative Economic Studies, 42 (1), 87-134.

Hunter, J./Schmidt (1990): Methods of Meta-Analysis: Correcting Error and Biases in Research Findings. Newbury Park. CA: Sage. 
Keenan, J./Aggestam, M. (2001): Corporate governance and intellectual capital: some conceptualizations, Corporate Governance, 9 (4), 259-275.

Koładkiewicz, I. (1999): Corporate Governance. International Perspective. PFPK - Poltext, Warsaw.

Koładkiewicz, I. (2002): The institutional shareholder- best practice: The National Investment Fund's experience, Corporate Governance, Vol. 10, 187-196.

Lewandowski, J./Szyszko, R. (1999): The governance of privatization funds in Poland, in: Simoneti, M./Estrin, S./Bohm, A. (1999): The Governance of Privatization Funds: Experiences of Czech Republic, Poland and Slovenia, Cheltenham: Edward Elgar.

Kołodko, G. (2000): Transition to a market and entrepreneurship: the systemic factors and policy options, Communist and Post-Communist Studies, 33, 271-293.

Morawski, W. (1998): Institutional Change, PWN, Warsaw.

Morgan, K. (1991): Innovating by networking. New models of corporate and regional development. Paper presented at the conference on The Development of Technology and Regional Development Change, Aalborg, Denmark.

Powell, W. (1990): Neither market nor hierarchy: network forms of organization. Paper presented at workshop on the Socio-Economics of Inter-Firm Cooperation, Berlin.

Romanowska, M. (1998): Capital groups strategies in Poland, in: Romanowska, M./Trocki, M./Wawrzyniak, B.: Capital Groups in Poland, Diffin, Warsaw.

Romanowska, M./Trocki, M./Wawrzyniak, B. (1998): Capital Groups in Poland, Diffin, Warsaw.

Sama, L./Papamarcos, S. (2000): Hofstede's IC dimensions as predictive of allocative behaviors: a meta-analysis, International Journal of Values-Based Management, 13, 173-188.

Simoneti, M., Estrin, S./Bohm, A. (1999): The Governance of Privatization Funds: Experiences of Czech Republic, Poland and Slovenia, Cheltenham: Edward Elgar.

Sztyber, W. (1997): The program of National Investment Funds in Poland, Economic Discussion Papers, No 37, Warsaw: Faculty of Economic Sciences, University of Warsaw.

Tricker, R. (1984): Corporate Governance. Aldershot: Gower Publishing Company.

Tricker, R. (2000). 2020 Vision: on corporate governance: Its scope, concerns and theories, Corporate Governance, 8 (1), 2-6.

Wawrzyniak, B./Koladkiewicz, I./Solarz, J./Trocki, M. (1998): National Investment Funds. Managing the New Structure. PWN, Warsaw.

Wawrzyniak, B. (2002): Polskie Grupy Kapitalowe. Perspektywa Europejska (Polish Capital Groups; European Perspective). WSPiZ, Warszawa.

Wiemer, J./Pape J. (1999): A Taxonomy of Systems of Corporate Governance, Corporate Governance: An International Review, 7 (2), 152-166. 